\section{Soybean germplasms evaluation for acid tidal swamp tolerance using selection index}

\author{
Heru Kuswantoro, 'Andy Wijanarko, \\ Dany Setyawan, ${ }^{2}$ Eddy William, ${ }^{3}$ \\ Ahmad Dadang, ${ }^{2}$ Made Jana Mejaya' \\ 'Indonesian Legume and Tuber Crops \\ Research Institute, Malang; \\ IIndonesian Center for Agricultural \\ Biotechnology and Genetic Resources \\ Research and Development, Bogor; \\ ${ }^{3}$ Indonesian Swampland Agricultural \\ Research Institute, Banjarbaru-South \\ Kalimantan, Indonesia
}

\section{Abstract}

Availability of fertile land on the island of Java in Indonesia decreases due to the shifting from agricultural land to non-agricultural land. Hence, an extensification of soybean culture to outer Java suboptimal land areas is needed, such as tidal swamp which occupies approximately 20.192 million hectares. The main limitations in this soil are soil acidity, Fe toxicity and excess water. To develop soybean varieties tolerant to acid tidal swamp, tolerant soybean gene resources are needed. Hence, glasshouse and field experiments were carried out to identify tolerant gene resources. The glasshouse experiment has been conducted using 185 genotypes of germplasm at the Indonesian Legume and Tuber Crops Research Institute, Malang, East Java. Selection was carried out by using a selection index method. The glasshouse experiment was followed by field experiment at the Belandean research station, Banjarbaru, South Kalimantan, using the best 17 genotypes selected from the glasshouse trial. Results showed that there was variability of response of each genotype to acidity and $\mathrm{Fe}$ toxicity. Therefore, assessment of soybean tolerance to acidity and Fe toxicity should be conducted by root growth. Based on selection index criteria, varieties of Lawit and Menyapa served as check tolerant varieties and showed lower growth than the 17 selected genotypes. In the field experiment, genotype MLGG 1087 was identified as the most tolerant and can serve as a gene resource tolerant to acid tidal swamp because it has the highest relative root growth on root dry weight, and the highest average of root and shoot dry weight.

\section{Introduction}

In an effort to fulfill soybean demand which reaches more than 2 million tons per year, growers encounter constraints related to the narrowing of fertile areas in Java island due to conversion of agricultural land area to nonagricultural land. This is reflected in a reduction in soybean planting areas from 1995 to 2004 by $6.1 \%$ per year and a decrease in soybean harvesting areas during the period 20002004 at a rate of $9.7 \%$ per year. Because of the decrease in harvested areas, the 2004 national production only reached 0.71 million tons. ${ }^{1}$ Hence, the fulfillment of soybean demand should be conducted through both intensification and extensification. The decrease in agricultural areas in Java Island suggested that extensification only can be conducted on the outer Java Island. However, the attempts made in the outer Java Island have mainly been with suboptimal land. One of the constraints in this suboptimal land is soil acidity, because the soils are dominated by ultisols, oxysol, and histosol. In Indonesia, some of the lands classified as suboptimal encompass acid soil and swamp areas. Indonesia has very wide swamp area, i.e. 33.4 million hectares; consisting of 20,192 million hectares of tidal area and 13,283 million hectares of waterlogged area. ${ }^{2}$

Tidal swamp is a marginal land and a fragile ecosystem. Its suitability for agricultural commodities in the original natural condition is classified as marginally suitable (S3) and moreover included in the category presently not suitable (N1). Many plant growing constraints on tidal area caused by saturated and anaerobic rhizosphere (mud, reduction reaction, oxygen and $\mathrm{H} 2 \mathrm{~S}$ gas deficiencies), existing of pyrite or sulfidic materials, $\mathrm{Al}, \mathrm{Fe}, \mathrm{Mn}$ toxicities, very acidic reaction of soil, and low natural fertility ( $\mathrm{P}, \mathrm{N}$ and $\mathrm{K}$ deficiencies, and poor bases). ${ }^{3}$ On land where pyrite has overcome oxidation, in aerobic conditions such as on shallow pyritic swamp areas, many problems will be presented; some of them are $\mathrm{Al}$, $\mathrm{Mn}$ and ferry $\left(\mathrm{Fe}^{3+}\right)$ toxicities because of low soil $\mathrm{pH}, \mathrm{P}$ deficiency, and perhaps also other macro nutrients deficiencies. While, in water logged conditions, when the water table reaches the surface or during rain, increasing $\mathrm{pH}$ caused by a reduction process leads to decreasing $\mathrm{Al}$ and $\mathrm{Mn}$ toxicities but increasing $\mathrm{Fe}^{2+}$, $\mathrm{H}_{2} \mathrm{~S}, \mathrm{CO}_{2}$ and water soluble organic acids toxicities. $^{4}$

Beside soil chemistry problems, an problems with water availability also have important role. Linkemer et al. ${ }^{5}$ reported that soybeans' early vegetative period and early reproductive stages were most sensitive to waterlogging. Further, it is reported that fewer pods per reproductive node lead to a decrease in pod production and finally yield reduction. At least two days of waterlogging during the final vegetative phase can reduce seed yield up to $18 \%$; while at an early reproductive phase it can decrease seed yield up to $26 \%{ }^{6,7}$ also reported a
Correspondence: Heru Kuswantoro,

Jl Raya Kendalpayak Km 8 Malang-Indonesia.

E-mail: heru@litbang.deptan.go.id

Key words: soybean, acid tidal swamp, Fe toxicity, germplasms, selection index.

Acknowledgment: the authors thank the State Ministry of Research and Technology of Indonesia for funding. Thanks also to Herb for revising the manuscript.

Received for publication: 7 October 2009.

Revision received: 23 February 2010.

Accepted for publication: 9 April 2010.

This work is licensed under a Creative Commons Attribution 3.0 License (by-nc 3.0).

(C) Copyright H. Kuswantoro et al., 2010

Licensee PAGEPress, Italy

International Journal of Plant Biology 2010; 1:e11 doi:10.4081/pb.2010.e11

significant negative correlation of flooding to the number of pods and seed yield. This case correlated with plant capacity to survive in oxygen deficiency condition. ${ }^{8}$

The low $\mathrm{pH}$ in soil due to the high $\mathrm{H}^{+}$ions concentration can affect plant growth and development by an $\mathrm{H}^{+}$ions toxic effect. However, the direct effect of $\mathrm{H}^{+}$ions on acid soil is difficult to determine, because in low $\mathrm{pH}$ conditions this correlates with $\mathrm{Al}, \mathrm{Mn}, \mathrm{Fe}$ and other mineral toxicities which are soluble in high concentrations, and essential nutrient availability such as $\mathrm{Ca}, \mathrm{Mg}, \mathrm{Mo}$, and $\mathrm{P}$ which are in suboptimal condition. ${ }^{9,10}$ Acid soil effects showed in soybean by different root growth responses, where tolerant genotypes had higher root length, and susceptible genotypes had suppression on growth root. ${ }^{11}$ On an Al-tolerant soybean cultivar, Schenkel ${ }^{12}$ reported that decreasing the nutrient solution from $\mathrm{pH} 6$ to 4.3 decreased total dry matter per pot up to $63 \%$ over the cultivar's average.

The complexity of problems on acid tidal swamp areas suggested a step by step problem solving approach. The main problem on acid tidal soil in South Kalimantan is Fe toxicity, so this problem needs to be the main solution by utilizing tolerant gene resources which serve as material in developing a tolerant variety.

\section{Materials and Methods}

\section{Glasshouse evaluation}

Research was conducted from February to March 2007 at ILETRI's greenhouse, Malang, East Java. Materials used in this experiment were 185 genotypes of soybean seeds from the 
Iletri collection, including two adaptive tidal swamp varieties, Lawit and Menyapa, as controls. These 185 genotypes are not only from native germplasm but also from overseas introductions. Factorial randomized compelete block design with two replications were used in this experiment. The first factor was low $\mathrm{pH}$ and consisted of two levels, i.e. a) aerated waterlogging with $\mathrm{pH} 7$ and b) unaerated waterlogging with $\mathrm{pH}$ 4.0. The second factor was genotype, and consisted of 185 genotypes. Aeration was proposed to provide root respiration and to avoid hypoxia and anoxia.

Seeds from each genotype were sterilized with $1 \%$ sodium hypochlorite for ten minutes, rinsed in deionised water and then germinated in sand with a nutrition solution containing $30 \mathrm{mg} \mathrm{N} \mathrm{L}-1\left(\mathrm{NH}_{4} \mathrm{NO}_{3}\right), 1 \mathrm{mg} \mathrm{P} \mathrm{L}{ }^{-1}\left(\mathrm{NaH}_{2} \mathrm{PO}_{4}\right.$ $\left.2 \mathrm{H}_{2} \mathrm{O}\right), 30 \mathrm{mg} \mathrm{K} \mathrm{L}-1\left(\mathrm{~K}_{2} \mathrm{SO}_{4} 7 \mathrm{H}_{2} \mathrm{O}\right), 2 \mathrm{mg} \mathrm{Fe} \mathrm{L}{ }^{-1}$ $\left(\mathrm{FeSO}_{4} 7 \mathrm{H}_{2} \mathrm{O}\right), 0.5 \mathrm{mg} \mathrm{Mn} \mathrm{L} \mathrm{L}^{-1}\left(\mathrm{MnSO}_{4} 4 \mathrm{H}_{2} \mathrm{O}\right)$, $0.5 \mathrm{mg} \mathrm{B} \mathrm{L-1}\left(\mathrm{H}_{3} \mathrm{BO}_{3}\right), 0.2 \mathrm{mg} \mathrm{Zn} \mathrm{L}{ }^{-1}\left(\mathrm{ZnSO}_{4}\right.$ $\left.7 \mathrm{H}_{2} \mathrm{O}\right), 0.01 \mathrm{mg} \mathrm{Cu} \mathrm{L}^{-1}\left(\mathrm{CuSO}_{4} 5 \mathrm{H}_{2} \mathrm{O}\right)$, and 0.005 mg Mo L ${ }^{-1}\left(\left(\mathrm{NH}_{4}\right)_{6} \mathrm{Mo}_{7} \mathrm{O}_{24} 4 \mathrm{H}_{2} \mathrm{O}\right) .{ }^{13}$ The acidity of the solution for sand culture was controlled at $\mathrm{pH}$ 7. After five days, seedlings were transplanted into aerated waterlogging with $\mathrm{pH} 7$ or unaerated waterlogging with $\mathrm{pH}$ 4.0. As long as plants were in normal solution, the solution was aerated using an aerator to avoid hypoxia and anoxia. During the stress treatment, the solution was not aerated and the $\mathrm{pH}$ of the solution was controlled between $4.0 \pm 0.1$. The nutrition concentration was held at the previous concentration.

Plants were observed at age 0 and 7 days after transplanting (DAT). After rinsing with deionised water, plants were divided into root and shoot. Each organ was weighted after dried in $80^{\circ} \mathrm{C}$ for 48 hours. Relative growth of each organ was measured according to Nursyamsi ${ }^{14}$ as follows:

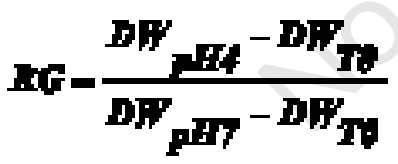

where:

$\mathrm{RG}=$ Relative growth

$\mathrm{DW}_{\mathrm{pH} 4}=$ Dry weight at $\mathrm{pH} 4$ treatment

$\mathrm{DW}_{\mathrm{pH} 7}=$ Dry weight at $\mathrm{pH} 7$ treatment

$\mathrm{DW}_{\mathrm{T} 0}=$ Dry weight at 0 day after transplanting

\section{Field evaluation}

Field evaluation was conducted at the Belandean research station, Banjarbaru, South Kalimantan from May to July 2007, using randomized complete block design with two replications. The tested genotypes in field evaluation were selected from glasshouse experimental evaluation. Stress treatment was conducted at one level, i.e. acid waterlogging. Land for field evaluation was chosen that was suitable for the research goal to obtain soybean

Table 1. Relative growth of several quantitative characters of 185 soybean seeds genotypes.

\begin{tabular}{lccc} 
Characters & Minimum & Maximum & Average \\
Root dry weight $\left(\mathrm{g} \cdot \mathrm{g}^{-1} \cdot\right.$ week $\left.^{-1}\right)$ & -1.64 & 13.50 & 1.29 \\
Shoot dry weight $\left(\mathrm{g} \cdot \mathrm{g}^{-1} \cdot\right.$ week $\left.^{-1}\right)$ & -5.44 & 10.03 & 1.04 \\
\hline Root length $\left(\mathrm{cm} \cdot \mathrm{cm}^{-1} \cdot\right.$ week $\left.^{-1}\right)$ & -5.32 & 8.05 & 0.40 \\
Hypocotyls length $\left(\mathrm{cm}^{-1} \mathrm{~cm}^{-1} \cdot\right.$ week $\left.^{-1}\right)$ & -7.50 & 11.08 & 0.67 \\
\hline Epycotyls length $\left(\mathrm{cm} \cdot \mathrm{cm}^{-1} \cdot\right.$ week $\left.^{-1}\right)$ & -1.63 & 9.54 & 1.43 \\
Plant height $\left(\mathrm{cm} \cdot \mathrm{cm}^{-1} \cdot\right.$ week $\left.^{-1}\right)$ & -15.63 & 32.74 & 1.44 \\
\hline
\end{tabular}

germplasm tolerant to acid tidal swamp. Before planting, land was cleared from weeds. Following clearing, a pool was prepared of approximately $1 \mathrm{~m}$ depth. Water irrigation was made from the pool with water from the tidal swamp. Water was flooded into the evaluation pool for a minimum of two weeks before soybean planting was conducted, in order to obtain an evaluation location that was appropriate with the natural condition of a tidal swamp. Similar planting was conducted with the glasshouse evaluation, where seeds were sowed into sand and then transplanted into treatment field when aged 5 days. Observation was carried out at age 0 and 14 days.

\section{Results and Discussion}

\section{Glasshouse evaluation}

Research was conducted by previously sowing the seeds in sand. After five days plants were transplanted into the treatment pool. Of the 185 soybean seed genotypes that were tested, 5 genotypes could not grow in neutral and acid stress treatment: MLGG 0713, MLGG 0812, MLGG 0816, MLGG 0836 and MLGG 0932. It was assumed that the 5 genotypes were sensitive to waterlogging or sensitive to transplanting conditions. Lack of oxygen was considered the main problem associated with waterlogging. ${ }^{15}$ In this research, waterlogging treatment with and without aeration had an affect on plant growth, especially on leaf chlorosis. However, the effect of waterlogging did not affect the plants' life. Boru et al. ${ }^{16}$ reported similar results while, during two weeks, the treatment without oxygen ( $100 \%$ gas $\mathrm{N} 2)$ or $80 \%$ reduction in oxygen had no impact on plant survival. In fact, as plants increased in age, they adapted with aerenchym and adventitious roots at the layer between water and air. ${ }^{16-18}$

\section{Relative growth}

The rate of relative weight root growth varied from -0.64-13.50 g.week ${ }^{-1}$ with an average of 1.29 g.week ${ }^{-1}$ (Table 1). Negative values showed that root growth of sensitive genotypes was terminated, the root was broken so the mass was decreased. This condition also occured with other observed parameters. On shoot measurments, such as shoot dry weight, hypocotyls length, epicotyls length and plant height, the negative value was probably due to the shrinking of mass or length of plant, as the result was shifted to other plant parts. On peanut, Kuskopf et al. ${ }^{19}$ stated that plants were allocated more $\mathrm{N}$ to roots than to shoots for amelioration of environment stress. This increased some organs and decreased other plant parts. While on root parameters, a negative value occured due to the brittleness of plant organ, so weight and size of root become lower than the early growth.

Genotypes of MLGG 0731 and MLGG 0511 had highest rate of relative root dry weight growth, i.e. 13.50 g.week ${ }^{-1}$ and 11.21 g.week $^{-1}$, respectively (Table 2 ). 0 n the other genotypes the rate of root dry weight growth was not as high as these 2 genotypes. While on shoot dry weight character, MLGG 0647 demonstrated the highest rate of growth reaching 10.03 g.week ${ }^{-1}$. Other rates of growth such as root, hypocotyls and epicotyls length, and plant height did not have same direction with weight root growth and shoot at the same genotypes. It indicated that there was no linkage among observed characters. The implication of such gene resources in plant breeding was to join the traits by crossing many parents with specific traits.

Root dry weight observation was the major observation concern in this research. Under the stress condition, it was seen that roots in all tested genotypes did not grow normally. This result suggested that the successes of treated stress condition, and genotype having good root were selected. Based on passive observation, it was seen that soybean was tolerant to acid waterlogging not only shown on root but also through all plant quantitave characters. The symptoms of toxic poisoned plants were chlorosis and leaf twisted ${ }^{20}$ and also hypocotyls and epicotyls shorterning. Leaf chlorosis was caused by transports of gibberellins and cytochinine acids to leaf, where these occurred to protect leaf membrane integrity. Reducing nitrogen transport from leaf to root also caused chlorosis as a result of decreasing protein and chlorophyll syntheses. ${ }^{21}$ $\mathrm{N}$ transport was very important because accu- 
Table 2. Relative growth of several characters of best 17 genotypes based on selection index.

\begin{tabular}{|c|c|c|c|c|c|c|c|}
\hline Genotypes & $\begin{array}{l}\text { Root dry weight } \\
\left(\mathrm{g} \cdot \mathrm{g}^{-1} \text { week }^{-1}\right)\end{array}$ & $\begin{array}{c}\text { Root length } \\
\left(\mathrm{cm.cm}^{-1} \text { week }^{-1} \text { ) }\right.\end{array}$ & $\begin{array}{l}\text { Shoot dry weight } \\
\left(\mathrm{g} \cdot \mathrm{g}^{-1} \text { week }^{-1}\right)\end{array}$ & $\begin{array}{l}\text { Hypocotyls length } \\
\left(\mathrm{cm.cm}^{-1} \text { week }^{-1}\right)\end{array}$ & $\begin{array}{l}\text { Epicotyls length } \\
\left(\mathrm{cm.cm}^{-1} \text { week }^{-1}\right)\end{array}$ & 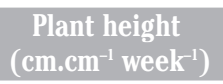 & $\begin{array}{l}\text { Selection } \\
\text { index }\end{array}$ \\
\hline MLGG 0731 & 13.50 & -0.32 & 1.23 & 0.67 & 1.21 & 0.40 & 3.0552 \\
\hline MLGG 0511 & 11.21 & ${ }^{-1.29}$ & 1.11 & 1.58 & 1.67 & 1.92 & 2.4594 \\
\hline MLGG 0170 & 6.88 & 0.80 & 1.45 & 0.88 & 1.52 & 1.72 & 1.8652 \\
\hline MLGG 0257 & 6.00 & 0.20 & 2.90 & -0.93 & 2.21 & 5.85 & 1.7672 \\
\hline MLGG 0305 & 7.25 & 0.00 & 1.81 & -3.50 & 1.48 & 0.91 & 1.6828 \\
\hline MLGG 0696 & 6.50 & 0.00 & 0.00 & 0.17 & 2.00 & 0.74 & 1.5317 \\
\hline MLGG 1087 & 5.88 & 0.12 & 0.40 & 0.00 & 1.18 & 1.01 & 1.4179 \\
\hline MLGG 0675 & 4.69 & 0.55 & 1.98 & 1.10 & 1.31 & 1.50 & 1.3444 \\
\hline MLGG 0858 & 4.50 & 0.52 & 2.57 & 0.00 & 2.01 & 1.90 & 1.3309 \\
\hline MLGG 0009 & 4.78 & 0.05 & 1.20 & 4.50 & 1.22 & 0.91 & 1.2908 \\
\hline MLGG 0770 & 1.47 & 2.62 & 0.75 & 11.08 & 1.44 & 0.69 & 1.1512 \\
\hline MLGG 0143 & 4.08 & 0.47 & 1.46 & 0.00 & 1.52 & 1.42 & 1.1507 \\
\hline MLGG 0647 & 3.08 & -0.22 & 10.03 & -0.02 & 1.60 & 1.36 & 1.1482 \\
\hline MLGG 0165 & 4.17 & 0.34 & 1.32 & 0.00 & 1.33 & 1.14 & 1.1246 \\
\hline MLGG 0238 & 2.83 & 1.63 & 1.82 & 0.19 & 1.55 & 1.29 & 1.0993 \\
\hline MLGG 0061 & 2.80 & 0.80 & 2.29 & 0.23 & 1.66 & 1.25 & 0.9619 \\
\hline MLGG 0592 & 1.50 & 0.96 & 1.64 & 5.10 & 1.49 & 1.25 & 0.7807 \\
\hline
\end{tabular}

Table 3. Relative growth rate of several quantitative characters of five national superior varieties to acid waterlogging.

\begin{tabular}{|c|c|c|c|c|c|c|c|}
\hline Genotypes & $\begin{array}{l}\text { Root dry weight } \\
\left(\mathrm{g} . \mathrm{g}^{-1} \text { week }^{-1}\right)\end{array}$ & 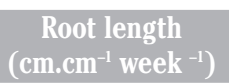 & $\begin{array}{l}\text { Shoot dry weight } \\
\left(\mathrm{g.g}^{-1} \text { week }^{-1}\right)\end{array}$ & $\begin{array}{l}\text { Hypocotyls length } \\
\left({\mathrm{cm} . \mathrm{cm}^{-1}}^{-1} \text { week }\right.\end{array}$ & $\begin{array}{l}\text { Epicotyls length } \\
\left({\mathrm{cm} . \mathrm{cm}^{-1}}^{-1} \text { week }^{-1}\right)\end{array}$ & 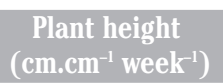 & $\begin{array}{c}\text { Selection } \\
\text { index }\end{array}$ \\
\hline Lawit & 0.79 & 0.00 & 0.95 & 0.66 & 0.99 & 8.34 & 0.6006 \\
\hline Malabar & 1.14 & 0.80 & 0.97 & -3.21 & 1.93 & 1.40 & 0.4757 \\
\hline Menyapa & -0.73 & 0.38 & 0.63 & 1.22 & 1.21 & 0.92 & 0.0300 \\
\hline Panderman & 0.50 & 0.40 & 0.55 & 0.00 & 1.45 & 1.22 & 0.2952 \\
\hline Sinabung & 0.63 & -0.50 & 0.06 & 0.00 & 0.97 & 0.75 & 0.1075 \\
\hline
\end{tabular}

mulation of $\mathrm{N}$ was associated with plant agronomic improvements. ${ }^{22}$ Beside, the oxidative stress also caused the decrease of total formed chlorophylls. ${ }^{23}$ Hence, relative growth observation conducted not only on root but also on shoot dry weight, root length, hypocotyls length, epycotyls length and plant height.

\section{Selection index}

To evaluate tolerant plants to acid waterlogging stress based on those six characters, selection index ${ }^{24}$ was used (with weighting relative growth of root dry weight relative: root length: shoot dry weight: hypocotyls length: epicotyls length: plant height $=1: 1: 0.75: 0.5: 0.5: 0.5$ ). Based on the six characters, selection index criteria was arranged as follows:

$\mathrm{Y}=0.2223 \mathrm{X}_{1}+0.1830 \mathrm{X}_{2}+0.0405 \mathrm{X}_{3}+0.0224 \mathrm{X}_{4}$ $+0.0262 \mathrm{X}_{5}+0.0415 \mathrm{X}_{6}$

where:

$\mathrm{X}_{1}=$ relative growth of root dry weight

$\mathrm{X}_{2}=$ relative growth of root length

$\mathrm{X}_{3}=$ relative growth of shoot dry weight

$\mathrm{X}_{4}=$ relative growth of hypocotyl length

$\mathrm{X}_{5}=$ relative growth of epicotyl length
$\mathrm{X}_{6}=$ relative growth of plant height

According to the selection index formula with limit of selection criteria over $0.75,17$ identified genotypes tolerant to acid waterlogging were obtained (Table 3). Genotype MLGG 0731 was on the first rank with an index value of 3.055 followed by MLGG 0511 and MLGG 0170 , while genotypes on 15,16 and 17 ranks were MLGG 0238, MLGG 0061 and MLGG 0592. These 3 genotypes' index selection value were $1.099 ; 0.962 ; 0.781$ respectively, where values of index selection were lower than MLGG 0731 and MLGG 0511 which was on the first and second rank (3.055 and 2.459). Hence, those 2 genotypes can serve as gene resources for acid waterlogging tolerance.

The performance of 5 varieties (Lawit, Malabar, Menyapa, Panderman, and Sinabung) is provided in Table 3. Of those 5 varieties, Lawit was more tolerant than the other 4 varieties with a selection index value of 0.6006 . This was followed by Panderman, Sinabung, Malabar and Menyapa. Lawit and Menyapa varieties in this research were commercial tolerant varieties, because these 2 varieties were released as tol- erant varieties in tidal acid swamp. However, in this research, Lawit and Menyapa were not included in the best $10 \%$ according to the selection index. This showed that the gene resource being evaluated was more tolerant (than Lawit and Menyapa) to acid waterlogging and is still numerous in the Indonesian germplasm collection. If compared between 2 tolerant varieties, Lawit and Menyapa with selected gene resources in this research, it was seen that Lawit and Menyapa had already died (7 day), while genotypes MLGG 0731 and MLGG 0511 were still living in acid waterlogging stress conditions. Tolerance differentiations among genotypes was caused by root character differentiation, e.g. differentiation of increasing $\mathrm{pH}$ in root area. ${ }^{25}$ In acid tolerant soybean genotypes, the increasing $\mathrm{pH}$ of the rhizosphere was faster than the sensitive genotypes. ${ }^{26}$ This was part of apoplasmic tolerance mechanism, i.e. plant ability to exudate or control toxic element such as Fe into hairy root cells. This mechanism included organic acid exudation, $\mathrm{pH}$ increasing of rhizospher and lignifications ${ }^{27}$ which appeared on each tested genotype. 


\section{Field evaluation}

The field evaluation was carried out in a similar way to the glasshouse evaluation using formerly sowed seed soybean in sand media. After five days, plants were transplanted into treatment media. The differences between the glasshouse evaluation and this field evaluation was that stress treatment was longer (14 days). When the field evaluation was conducted, water acidity degree analysis showed $\mathrm{pH}$ 3.5. So this evaluation showed that selected genotypes from the field will have higher tolerance than glasshouse selected genotypes.

According to root dry weight criteria, MLGG 1087 genotype had first rank position with an average root dry weight $0.024 \mathrm{~g}$; followed by MLGG 0511 and MLGG 0731 with rate 0.016 and $0.013 \mathrm{~g}$, respectively. But based on root length average, genotype MLGG 0592 had first rank followed by MLGG 0511 and MLGG 0009, while root length of MLGG 1087 was shorter than the average of all genotypes. On shoot dry weight characters, genotype MLGG 1087 also ranked first with an average of $0.072 \mathrm{~g}$, where this value was higher than two times the average of all genotypes. For hypocotyls length characters, MLGG 0238 had the longest hypocotyls (18.12 cm) followed by MLGG $0592(17.84 \mathrm{~cm})$ and MLGG $0257(17.68 \mathrm{~cm})$. Genotype of MLGG 1087 with highest shoot dry weight had lower hypocotyl length than average genotypes. It means that MLGG 1087 had hypocotyl diameter higher than other genotypes (Table 4). Genotypes MLGG 1087 had the highest shoot dry weight. This may be due to a) this genotype can eliminate Fe through oxidation in rhizosphere and exudation of Fe from plant tissues, or b) $\mathrm{Fe}$ is inactivated in plant tissues. Wasiaturrohmah ${ }^{26}$ reported the occurrance of faster $\mathrm{pH}$ increase of identified Fe tolerant genotypes in the rhizosphere. A similar case was found in rice, where differences among varieties in excretion of $\mathrm{OH}$ - lead to $\mathrm{pH}$ differences in rhizosphere. A variety exudating more $\mathrm{OH}^{-}$could increase $\mathrm{pH}$ and absorb less Fe. On the other hand, a variety exudating less $\mathrm{OH}^{-}$ could not increase soil $\mathrm{pH}$ leading to a greater absorbtion of Fe..$^{28}$ Differences in Fe absorbtion in root and leaf by plant depend on the concentration. Mehraban et al. ${ }^{23}$ stated that up to 250 $\mathrm{mg} / \mathrm{L} \mathrm{Fe}$ content accumulated in root was higher than in leaf, but in concentrations of 500 $\mathrm{mg} / \mathrm{L} \mathrm{Fe}$ content in leaf was higher than in root.

\section{Conclusions}

Waterlogging affected leaf chlorosis on plants, but did not cause plant death; whilst Fe toxicity and media acidity affected growth of tested genotypes. The variety Lawit was more tolerant than the variety Menyapa, which indicated that Lawit was more suitale as check

Table 4. Average of some quantitative characters of 17 selected genotypes (from glasshouse experiment) to acid waterlogging on field experiment.

\begin{tabular}{lcccc} 
Genotypes & $\begin{array}{c}\text { Root dry } \\
\text { weight }(\mathrm{g})\end{array}$ & $\begin{array}{c}\text { Root length } \\
(\mathrm{cm})\end{array}$ & $\begin{array}{c}\text { Shoot dry } \\
\text { weight }(\mathrm{g})\end{array}$ & $\begin{array}{c}\text { Hypocotyls } \\
\text { length }(\mathrm{cm})\end{array}$ \\
MLGG 0009 & 0.006 & 10.780 & 0.045 & 16.420 \\
MLGG 0061 & 0.006 & 10.100 & 0.038 & 15.243 \\
\hline MLGG 0143 & 0.006 & 8.100 & 0.015 & 16.200 \\
MLGG 0165 & 0.007 & 7.567 & 0.013 & 14.980 \\
\hline MLGG 0170 & 0.008 & 9.030 & 0.018 & 14.910 \\
MLGG 0238 & 0.009 & 9.470 & 0.030 & 18.120 \\
\hline MLGG 0257 & 0.010 & 8.067 & 0.027 & 17.683 \\
MLGG 0305 & 0.012 & 9.930 & 0.025 & 13.660 \\
\hline MLGG 0511 & 0.016 & 11.111 & 0.016 & 14.167 \\
MLGG 0592 & 0.008 & 11.322 & 0.037 & 17.844 \\
\hline MLGG 0647 & 0.010 & 8.500 & 0.034 & 14.356 \\
MLGG 0675 & 0.011 & 9.000 & 0.036 & 14.167 \\
\hline MLGG 0696 & 0.011 & 9.250 & 0.051 & 15.917 \\
MLGG 0731 & 0.013 & 7.643 & 0.028 & 14.417 \\
\hline MLGG 0770 & 0.003 & 10.038 & 0.013 & 13.789 \\
MLGG 0858 & 0.010 & 8.589 & 0.057 & 14.078 \\
\hline MLGG 1087 & 0.024 & 9.175 & 0.072 & 12.350 \\
Average & 0.010 & 9.275 & 0.033 & 15.194 \\
\hline
\end{tabular}

variety for acid tidal tolerance. Based on the selection index on the rate growth, 17 tolerant genotypes were identified, where they had relative growth higher than varieties of Lawit and Menyapa. Genotypes MLGG 1087 and MLGG 0511 were identified as the gene resources tolerant to acid tidal swamp based on root dry weight characteristics. The tolerant genotype MLGG 1087 was also supported by the highest average of root and shoot dry weight.

There is a need to screen tolerant gene resources using other germplasm collections to find other soybean genotypes tolerant to acid tidal swamp in order to increase the probability of developing soybean varieties tolerant to acid tidal swamp. Genotype MLGG 1087 can be used as an acid tidal swamp tolerant gene resource since it has the highest root and shoot dry weight.

\section{References}

1. Deptan. Prospek dan Arah Pengembangan Agribisnis Kedelai. Badan Penelitian dan Pengembangan Pertanian. Departemen Pertanian. 2005.

2. Alihamsyah T, Sarwani M, Jumberi A, et al. Lahan pasang surut: Pendukung ketahanan pangan dan sumber pertumbuhan agribisnis. Balai Penelitian Pertanian Lahan Rawa. Banjarbaru. 2003;54 hlm.

3. Sudarsono. Pemanfaatan dan pengembangan lahan rawa/pasang surut untuk pengembangan pangan. Hal. 81-94. Dalam
Irsal Las, et al (eds) Prosiding Seminar Nasional Sumber Daya Lahan. Hasil Penelitian Tanah dan Agroklimat. Pusat Penelitian Tanah dan Agroklimat. Badan Litbang Pertanian. 1999.

4. Subagyo $\mathrm{H}$ and Widjaja-Adhi IPG. Peluang dan kendala pembangunan lahan rawa untuk pengembangan pertanian di Indonesia. Hal. 13-50. Dalam Kurnia, U. et al (eds) Prosiding Pertemuan pembahasan dan Komunikasi Hasil Penelitian Tanah dan Agroklimat. Pusat Penelitian Tanah dan Agroklimat. Badan Litbang Pertanian. 1998.

5. Linkemer G, Board JE and Musgrave ME. Waterlogging effect on growth and yield components of late-planted soybean. Crop Sci 1998;38:1576-84.

6. Scott HD, deAngulo J, Daniels MB and Wood LS. Flood duration effects on soybean growth and yield. Agron J 1989; 81:631-6.

7. Sullivan M, VanToai T, Fausey N, et al. Evaluating On-Farm Flooding Impacts on Soybean. Crop Sci 2001;41:93-100.

8. Dennise ES, Dolferus R, Ellis M, et al. Molecular strategies for improving waterlogging tolerance in plants. J Expr Bot 2000;51:88-97.

9. Howeler RH. Identifying plants adaptable to low pH conditions. p. 885-904. In: R.J. Wright, et al. (Eds.). Plant-soil interaction at low pH. Kluwer Academic Publisher. Netherlands. 1991.

10. Widjaja-Adhi IPG. Pengapuran tanah masam untuk kedelai. pp. 171-188. Dalam 
Somaatmadja S, Ismunadji M, Sumarno, Syam M, Manurung SO dan Yuswadi. (Eds). Kedelai. Pusat Penelitian dan Pengembangan Tanaman Pangan. Bogor. 1985.

11. Sunarto. Studi fisiologi dan genetik ketenggangan kedelai terhadap keracunan aluminium. Disertasi Doktor. Fakultas Pascasarjana Institut Pertanian Bogor. 1985.

12. Schenkel W. Cultivar spesific aluminum tolerance of soybean. p. 100-103. Dalam L.W. Gunawan, N. Sunarlim, T. Handayani, B. Soegiarto, W. Adil, B. Priyanto, dan Suwarno (Eds.). Prosiding Lokakarya Penelitian dan Pengembangan Produksi Kedelai di Indonesia 1996. Badan Penelitian dan Pengembangan Pertanian. Kementrian Pendidikan, Sains, Riset dan Teknologi Jerman. 2000.

13. Osaki M, Watanabe T, Tadano T. Beneficial effect of aluminium on growth of plants adapted to low pH soils. Soil Sc Plant Nutr. 1997;43:551-63.

14. Nursyamsi D. Aluminum Tolerance of Tropical Food Crops. Thesis. Graduate School of Agriculture, Hokkaido University. Japan. 2000.

15. Kozlowski TT. Extent, causes, and impact of flooding. pp. 1-7. In: T.T. Kozlowski (Ed.). Flooding and Plant Growth. New York. Academic Press. 1984.

16. Boru G, VanToai T, Alves J, et al. Responses of soybean to oxygen deficiency and ele- vated root-zone carbon dioxide concentration. Annals of Botany 2003;91:447-53.

17. Anwar N. Respon Beberapa Genotipe Kedelai (Glycine max (L.) Merril) terhadap Genangan. Skripsi. Fakultas Pertanian Universitas Brawijaya Malang 2008.

18. Bacanamwo M, Purcell LC. Soybean root morphological and anatomical traits associated with acclimation to flooding. Crop Sci 1999;39:143-9.

19. Kuskopf B, Walsh K, Armstrong R. Legume shoot and root $\mathrm{N}$ accumulation under water stress. 2003. http://www.regional. org.au/au/asa/2003/p/3/kuskopf.htm (accessed 7 February 2007)

20. Albano JP, Miller WB, Halbrooks MC. Iron toxicity stress causes bronze speckle, a specific physiological disorder of marigold (Tagetes erecta L.) J Amer Soc Hort Sci 1996;121:430-7.

21. Pezeshki SR. Plant responses to flooding. In: R.E. Wilkinson. (Ed.). Plant Environment Interactions. Marcel Dekker Inc. New York. 1994;pp. 289-312.

22. Cregan PB and Yaklich RW. Dry matter and nitrogen accumulation and partitioning in selected soybean genotypes of different derivation. Theor Appl Genet 1986;72:7826.

23. Mehraban P, Zadeh AA, Sadeghipour HR. Iron toxicity in rice (Oryza sativa L.), under different potassium nutrition. Asian Journal of Plant Sciences 2008;7:251-259.
24. Singh RK, Chaudary BD. Biometrical Methodes in Quantitative Genetic Analysis. Kalyani Publisher. New Delhi 1979.

25. Foy CD. Physiological effect of hydrogen, aluminum, and manganese toxicities in acid soil. In: Soil Acidity and Liming (Fred Adams Eds.). American Society of Agronomy, Inc. Crop Science Society of America, Inc. Soil Science Society of America, Inc. Madison, Wisconsin USA. 1984.

26. Wasiaturrohmah. Respon Plasma Nutfah Kedelai (Glycine max (L.) Merril) terhadap Keracunan Fe. Skripsi. Jurusan Biologi. Fakultas Sains dan Teknologi. Universitas Islam Negeri Malang. 2008.

27. Ermolayev V. Isolation of genes involved in soybean response to Al toxicity under Low pH condition. p.15-24. In: N. Sunarlim, M. Machmud, W.H. Adil, F. Salim, and I.N. Orbani (Eds.). Proceeding of Workshop on Soybean Biotechnology for Aluminum Tolerance on Acid Soils and Disease Resistance. Federal Ministry for Education and Research, Germany. Central Research Institute for Food Crops. Bogor. 2001.

28. Suhartini T. Perbaikan Varietas Padi Untuk Lahan Keracunan Fe. Buletin Plasma Nutfah 2004;Vol 10 No 1: http:// indoplasma.0r.id/publikasi /bulletin_pn/ abstrak/bulletin pn1012004tintin.htm (Accessed 7 April 2007). 